\title{
FROM BUBBLE TO SUSTAINABLE ECONOMY IN THE BALTIC STATES
}

\author{
Olli-Pekka Hilmola \\ Lappeenranta University of Technology, LUT School of Industrial Engineering and Management \\ Kouvola Unit, Prikaatintie 9, 45100 Kouvola, Finland \\ Fax: +358 5344 4009. E-mail: olli-pekka.hilmola@lut.fi
}

\begin{abstract}
The Baltic States became independent in the early 90's, when the iron wall collapsed in the whole Eastern Europe. Thereafter, development in economic terms was rapid and particularly manufacturing and transportation sectors were responsible for prosperity formation. However, after late 90's situation changed, and boom was apparent in credit led real estate, finance, retail and construction sectors. As these sectors are all domestically oriented, and while the Baltic States in this credit boom period did not experience any trade surpluses, it was evident that credit crunch in 2008-2009 affected economies severely. This research work shows that the Baltic States need to change again weight in Foreign Direct Investment (FDI) for manufacturing and transportation, sectors which have been supported previously only by European Investment Bank and EU Cohesion fund. FDI is vital for the Baltic States, since they have been for long time net receivers of capital, and GDP has greatly been dependent on these inflows. However, future prosperity is only built with export oriented FDI.
\end{abstract}

Keywords: the Baltic States, FDI, loans, EU cohesion, manufacturing, transportation

\section{Introduction}

Credit crunch of USA during years 2008-2009, which led to global economic slowdown, hit hard all the Baltic States [1]. Experienced change in downsize was very sudden, and even private sector actors were entirely unaware of its magnitude [1]. Therefore, unemployment increased within very short time [1-2] and construction sector was severely hit [2-3]. However, not only domestic economy led sectors were suffering, but this has been present also in export industries, like metal industry, which was experiencing 40\% slump in orders in Latvia (the largest export industry; [4]).

However, root problem in the Baltic States for these sudden negative changes was the economic structure formation and renewal, which took place during previous boom time. Relatively loose monetary policy of banks (international phenomenon then) resulted in fixed capital investments, and it has been analysed that in Lithuania during years 1995-2009 these fixed capital investments alone explained 91.54\% from GDP change [3]. Even if investments soared, and construction industry experienced boom period [2], other sectors, like export based manufacturing was continuously declining [5-6]. Similar situation happened with e.g. agriculture [3]; EU support has been argued here to be effective, that this branch even exists in the Baltic States today (volumes were continuously declining before EU membership; [7]). So, the problem of the Baltic States in general was that there did not exist any seriously taken industrial export arm, which could have aided their recovery out of the crisis with agreed and implemented lower salary levels. The Baltic States economies remind in miniature scale that of USA; in large extent their economic growth model was based on demand alone, not on supply. Therefore, it is not surprising to find out that Latvia has stated that export based manufacturing is their main development objective [6]. Challenge in export industries is that they are low technology companies (mostly food and beverages; [8; 6]), and main customers are in Europe [9]. This low-technology status mostly concerns Lithuania and Latvia. Based on research of Bernatonyte [9], Estonia is the most competitive in export industries, and two other Baltic States follow it with considerable distance. However, it should be noted that even in Estonia the industrial renewal is needed, e.g. the readiness for $\mathrm{CO}_{2}$ emission prevention and year 2020 and 2030 reduction targets could be higher as industries will most probably face increasing electricity prices due to $\mathrm{CO}_{2}$ emitting production processes of heat and electricity production [10].

Situation is not entirely hopeless, as EU cohesion funding is plenty during program period of 2007-2013 for all the Baltic States and continues to be so in the future cohesion funding rounds. Most of this granted funding was unused before the crisis, e.g. Lithuania only had used one third of them before the credit crunch [11]. Similarly Estonia reports in program webpages, that half of the entire funding is used in their country now, but rest of the projects for the end of 2013 are agreed, and costs will accumulate in late year 2012 and mostly in 2013 [12]. These funds are, of course, hope for a better future, since their use now in the challenging times is replicating Keynesian stimulus of economic downturns. 
This research is structured as follows: Section 2 portrays economic development in the Baltic States within recent decade. Strengths and weaknesses are reviewed briefly in this section, too. Thereafter, in Section 3 FDI inflows are examined in long-term perspective from all the Baltic States by industrial branches and countries involved in this activity. Role of international lending organizations (like EIB and ERBD) is analysed in Section 4, where it is shown that loans and especially the role of EIB has increased in recent years. EU cohesion funding is reviewed in longitudinal perspective in Section 5. Research work is concluded in Section 6, where also avenues for further research are being provided.

\section{Economic Development in the Baltic States}

All the Baltic States were growth tigers in the previous decade, and economic prosperity in national currency terms grew at least $10 \%$ p.a. before credit crunch. However, if we measure GDP change in euro terms, Latvia was experiencing some IT bubble burst problems in 2002-2003, but recovered strongly out of this (in national currency GDP growth was still 10\%, but this mostly caused due to depreciation of currency). Signs of overheated economy were very much present in year 2007, when GDPs grew 20-30\% p.a. (Figure 1). As will be shown later on this research work, overheating was caused by the massive capital inflows to the countries, particularly improvement of FDI inflows. However, as uncertainties in the world economies started to be present, investment activity disappeared suddenly as confidence on future growth was hurt. This eroded economic growth rather suddenly. Of course longterm loans taken from EIB and structural funds used out of EU cohesion helped a bit, but we may note that in year 2009 decline was massive. GDPs declined by 15-19\% then. Thereafter all three countries have experienced recovery process, but still in absolute terms GDPs of year 2011 were below the level of year 2008. During year 2012 Estonia (+6.6\%) and Lithuania (+6.7\% in EUR terms) passed GDP level of year 2008, and also Latvia is showing strong growth (+10.1\% in EUR terms), but in absolute terms is still slightly below year 2008 top.

Among investment attraction, all three Baltic States hold naturally important role as transit cargo locations for eastern (Russia, Ukraine, Byelorussia, Kazakhstan etc.) export of raw materials and/or import of consumer goods. This also affects greatly on employment and consumption, in turn having connection on GDP growth. In period of 2000-2009 these three countries had continuously changing position in transit cargo handling (e.g. [13]). For example, Estonia lost significantly coal transports during the decade perspective (development was in part fostered by small political crisis with Russia in 2007), but in turn Latvia was able to grow significantly in coal transit with sea port of Riga (capital city). However, in oil handling and fertilizers Latvia and Estonia have experienced decline in decade perspective, while Lithuania has grown considerably. In containers (general cargo) only Riga sea port in Latvia has been able to show in decade perspective clear growth - Lithuania and Estonia are looking also promising in this respect [14]. So, we could argue that transit transport is messy topic to be connected directly in GDP growth (as it changes between three Baltic States so rapidly), however, we may conclude that crisis in year 2009 took significant part from handling volumes away, and in turn caused GDP slump in crisis year. Declines before this crisis year were in parts caused due to rapidly deteriorating business climate, but also due to political tensions.

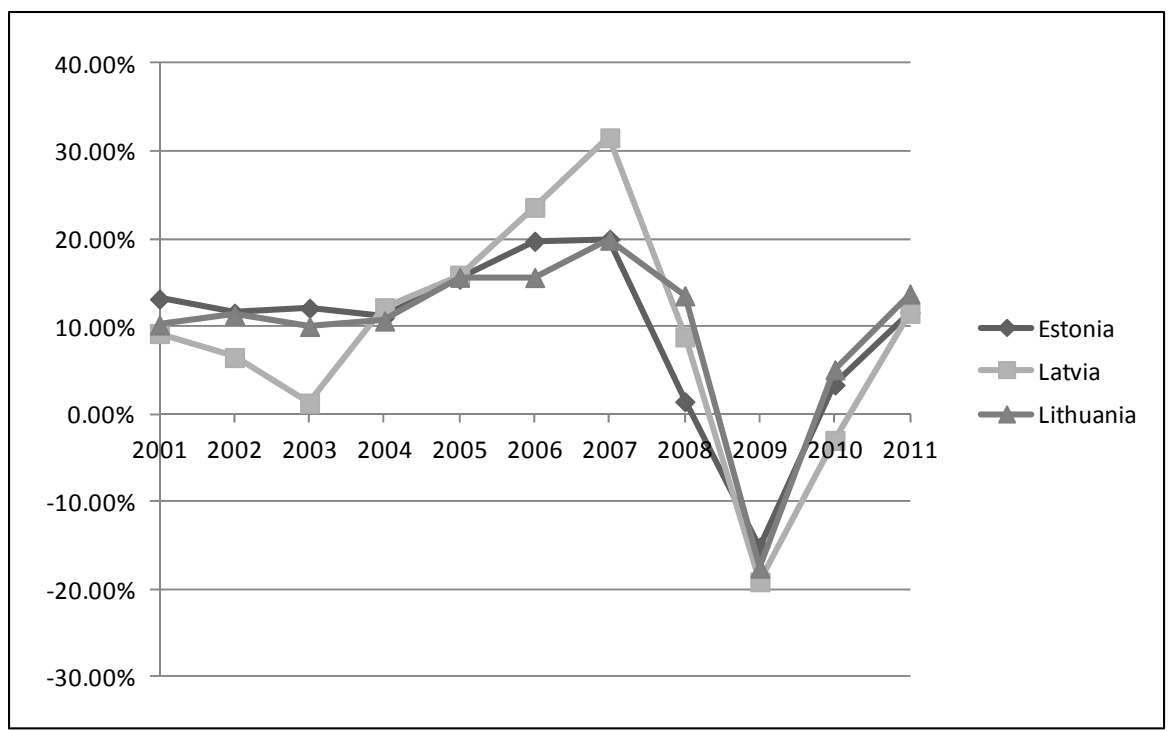

Figure 1. Gross Domestic Product (GDP) change in the Baltic States during previous decade (GDP converted to Euros with BOF [15]). Source: Statistics Estonia [16], Central Statistical Bureau of Latvia [17], Statistics Lithuania [18] 
As an anomaly to the Baltic States acts the United States. Similarly to USA, all the Baltic States significant trade deficits (these considerably widened after early 2000; recent years, see Figure 2) have recorded for years. After credit crisis situation has still remained, mostly due to high priced oil (was, of course, problematic also during growth period; see e.g. for Switzerland, Atukeren [41]), which all the Baltic States need to import from abroad. However, boom period of early 2000 was mostly caused by domestic sectors, and investments did not see manufacturing as an opportunity. Actually it is so that the Baltic States enjoyed healthy manufacturing development in 90's, but in ten recent years Asia has took over its share from this activity. Typically this meant that manufacturing units (e.g. subcontracting) were relocated to Asia. This concerns very many such branches as electronics and light weighted product production. So, in simplistic terms trade deficits mean that all three countries are in need of more capital (loans), either to be taken by private or public sector. Of course, capital could appear in form of FDI, too, or as EU structural support. It is open question, how long time capital in-flight could substitute uncompetitive export structures.

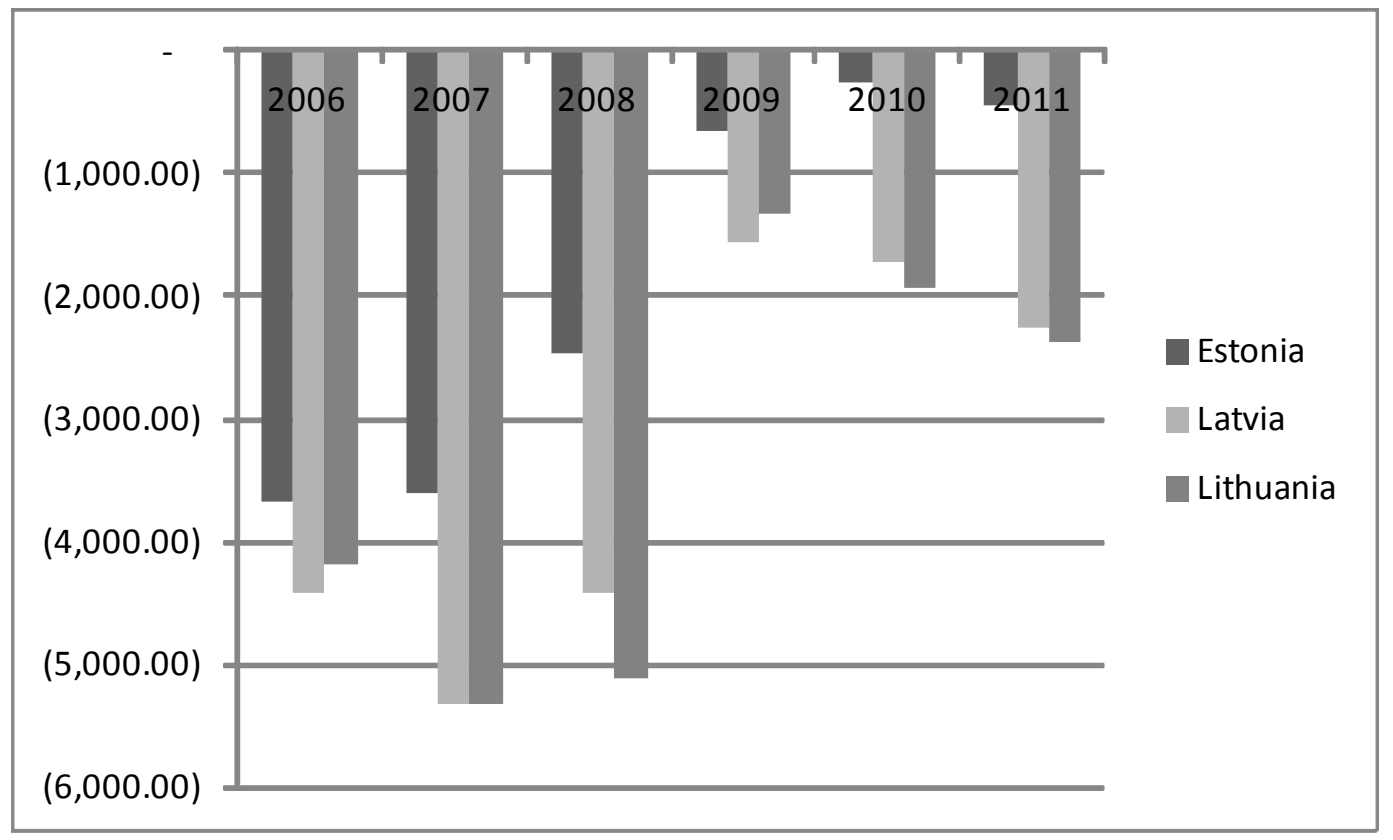

Figure 2. Trade deficit of the Baltic States within period of 2006-2011 (in mill. euros). Source: UN Comtrade [19]

As observing the development of trade account after crisis, only Estonia has started to show development, where exports could potentially in forthcoming years to be in parity with imports (Figure 2). However, situation in Latvia and Lithuania is repeating life before crisis - trade deficits in year 2011 were already more than two billion euros, and trend in both countries is strikingly downwards. This is not minor issue as in year 2011 Lithuanian trade deficit was one fourth from GDP, and Latvian in turn roughly one sixth. Year 2012 has not changed situation that much, Estonian trade deficit has increased slightly above 1 billion EUR, followed by 2 billion EUR deficit of Latvia and 2.56 billion EUR deficit of Lithuania. So, from trade account perspective recovery is not that sustainable, especially in case of Latvia and Lithuania.

Rapid expansion of manufacturing based export activity is very doubtful in all three economies (Figure 3) as all have followed the same pattern in the job loss during period of 2008-2012. Basically from the first quarter of year 2008 to the end of 2010 approx. 30\% of manufacturing working places were lost. Of course, during years 2011-2012 small recovery has been taking place, but still from early 2008 all countries are missing one fourth of working places. Job loss in this scale means that factories have streamlined further their operations, and expansion of production volumes is difficult or even impossible in large extent within future. Therefore, trade deficit showed on Figure 2 could be changed only with making import amounts lower. One potential is energy, which all of these countries are largely dependent on foreign sources. 


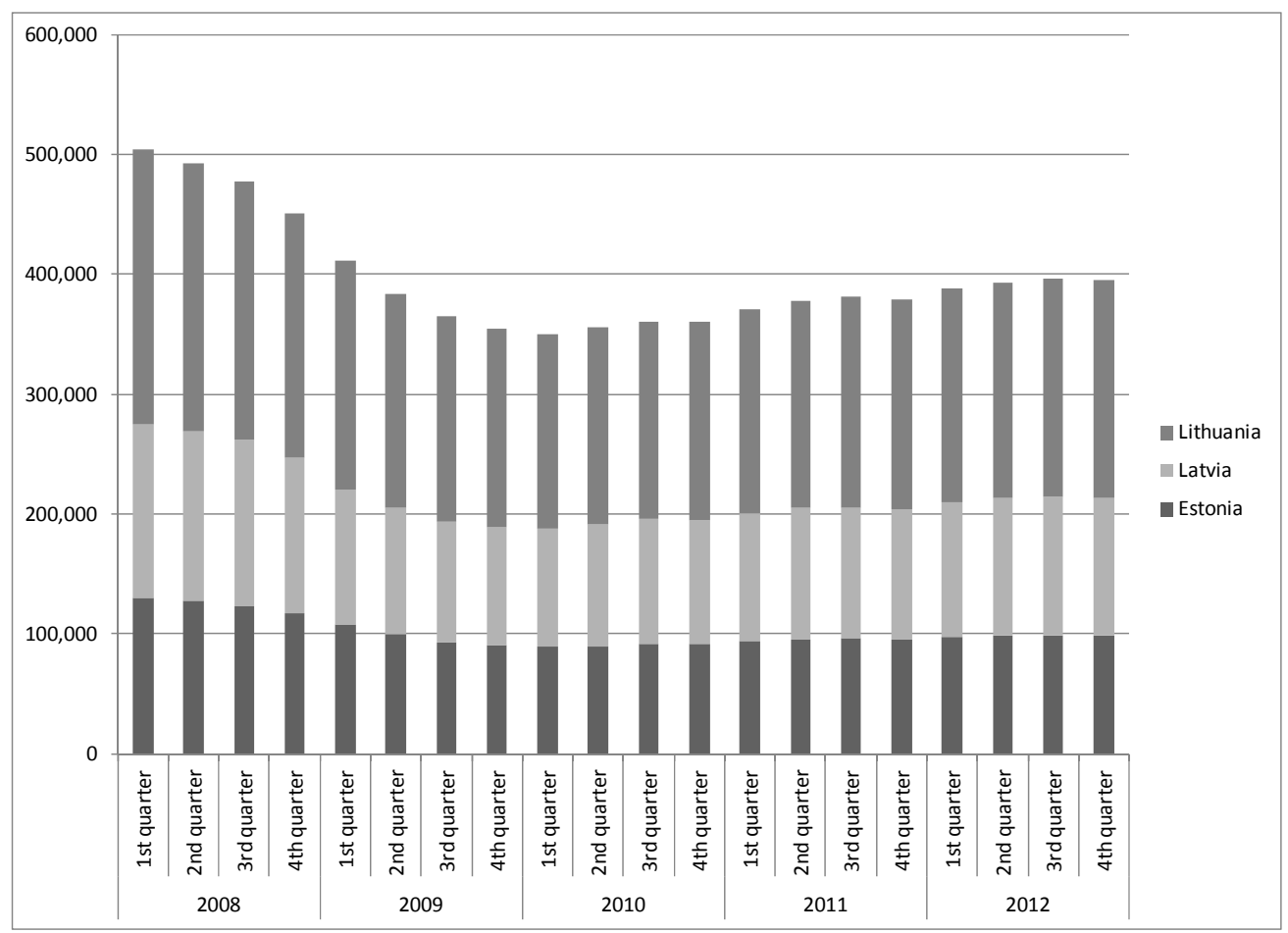

Figure 3. Manufacturing sector employment (\# of posts) in three Baltic States during period of 2008-2012. Source: Statistics Estonia [16]), Central Statistical Bureau of Latvia [17], Statistics Lithuania [18]

\section{Foreign Direct Investments in the Baltic States}

As the Baltic States could be classified as emerging economies (actually typical term was "Baltic Tigers”, used e.g. banks such as Credit Suisse [20] and magazine The Economist [21]) in European landscape during the previous decade time, their Foreign Direct Investment (FDI) have followed same emerging pattern. This experienced development was also the main reason, why GDP contracted in such significant manner during credit crunch, and in turn resulted in high unemployment rates. Three Baltic States' economies experienced severe boom in real estate, finance, wholesale and construction sectors and in their interaction (growth was domestic oriented and endogenous interactions with increasing amount of foreign investments that created bubble). As world economy was in general going through very loose monetary policy after IT bubble burst, these sectors attracted impressive amount of funding from foreign investors. This is apparent in longitudinal development of FDI in Estonia (Figure 4), Latvia (Figure 6) and Lithuania (Figure 8). It is interesting to note that in Estonia these four mentioned domestic market focused sectors accounted more than $70 \%$ of total FDI position in year 2007, as in Latvia more than 65\% in year 2008 and in Lithuania more than 45\% in year 2008.

During the last decade time period all the Baltic States were experiencing high GDP growth (until credit crunch slump), which was accompanied with continued deficits in trade accounts (also concluded in Ojala et al. [22]). Mostly much higher amount of FDI as compared what the Baltic States themselves invested abroad was the success formula. FDI dominance is the case still today, in Estonia country has more than 3.5 times investments from abroad than what it has invested to other countries, Latvia in turn has more than 13 times, and Lithuania nearly 7 times.

Economy overheating in year 2007 could be detected from Figures 4, 6 and 8. FDI inflows just spiked in this year rather significantly, and, of course, resulted on GDP growth of 20-30\%. This growth stopped entirely on credit crunch crisis during years 2008-2009, but mostly caused FDI to halt (not new inflows, but investments remained). Only Lithuania experienced declining FDI development, so namely FDI outflows. It also could be argued that most recent recovery is caused by the strength of FDI inflows, particularly growth experienced in years 2011-2012 (this last year 2012 not shown in Figures 4-9, but FDI growth has accelerated in Estonia from year 2011, in other two Baltic States it has been growing, but not like in 2011). 
As domestic oriented sectors were taking in attention during the previous decade, manufacturing and transportation have been rather slow growing in terms of FDI. However, in positive respect these two sectors have all still shown some growth in three Baltic States within chosen observation periods. What is not apparent from FDI statistics is that manufacturing has transformed increasingly as low tech and local. Export industries which are left are most competitive in Estonia. In Lithuania large proportion of manufacturing in FDI could be explained with oil refinery ownership changes.

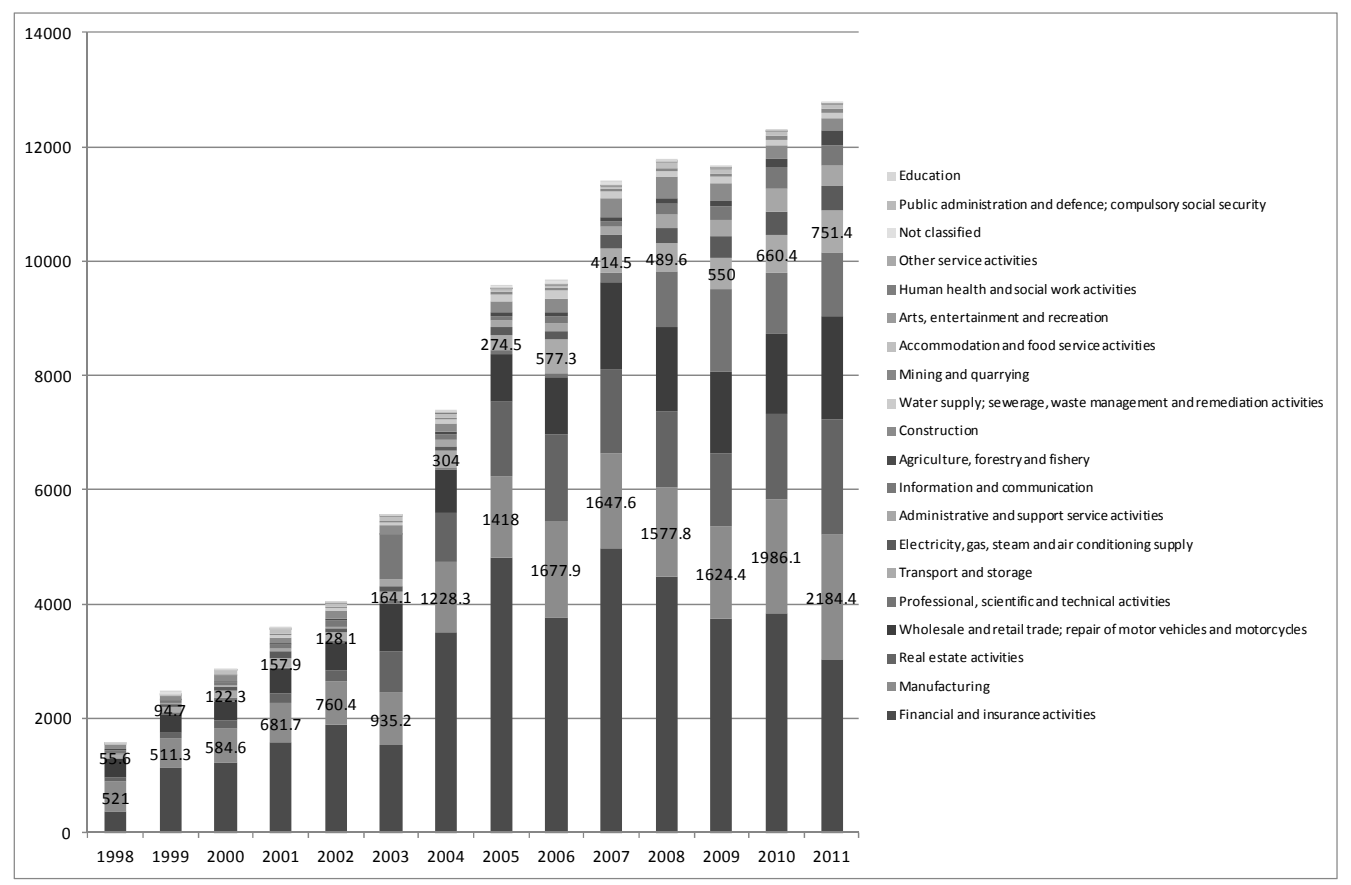

Figure 4. Foreign Direct Investments to Estonia (in million Euros) by branch within period of 1998-2011 (position in the end of the period). Source (data): Bank of Estonia [23]

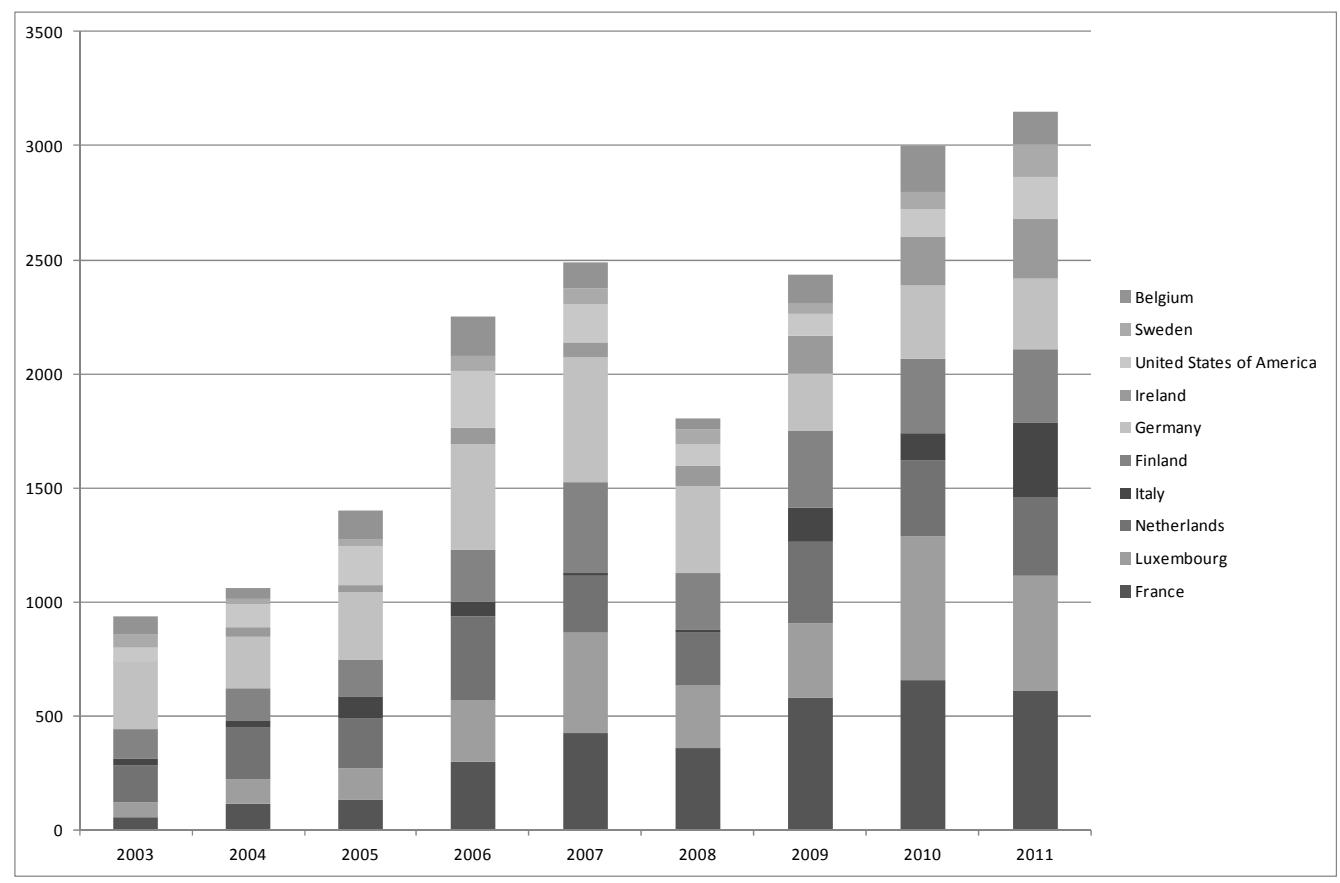

Figure 5. Ten most important FDI countries (in million Euros) for Estonia (ascending order with most recent year, 2011). Source (data): Bank of Estonia [23] 


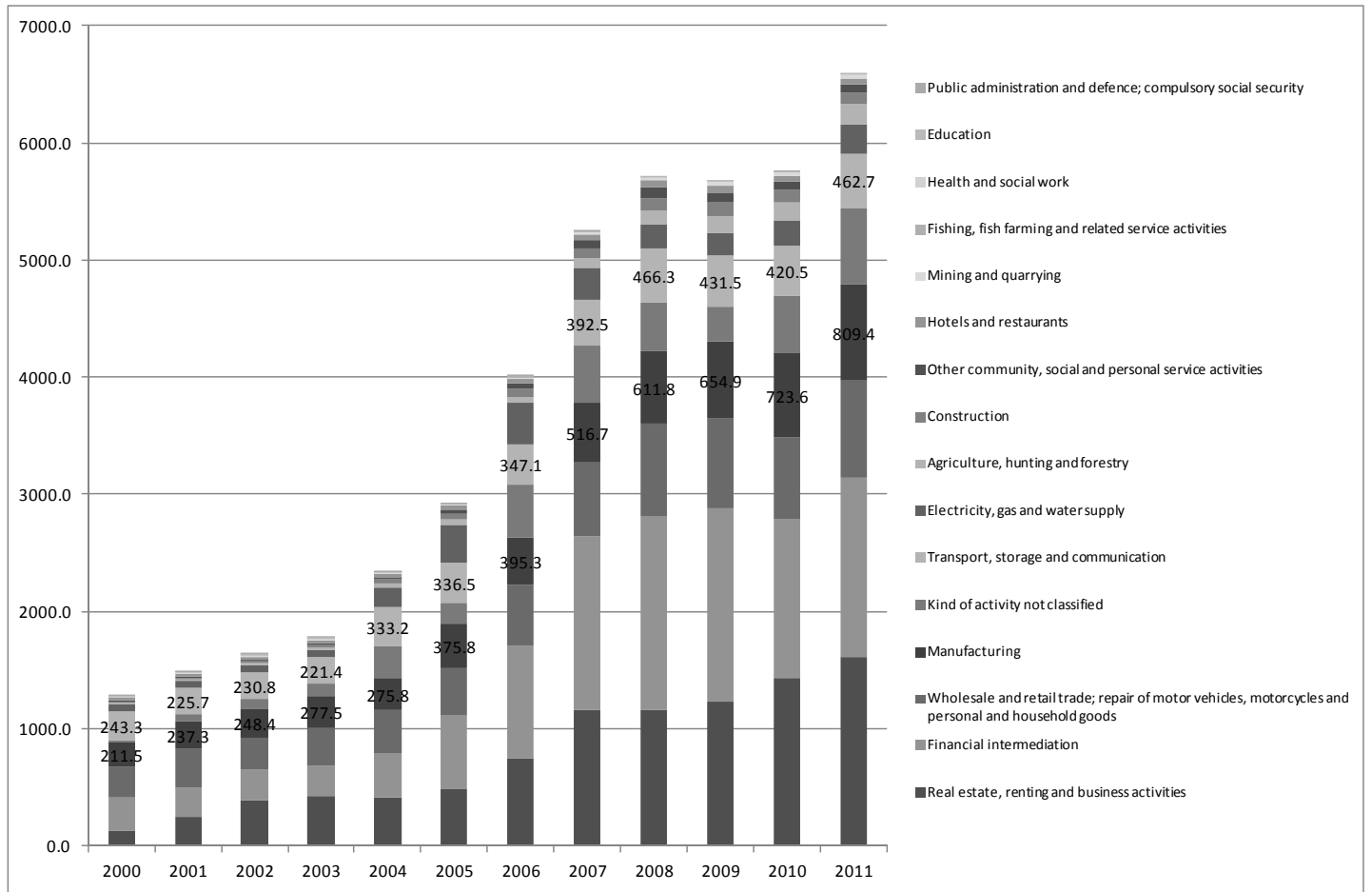

Figure 6. Foreign Direct Investments to Latvia (in million Lats as 1 Lat was 1.423 Euros at the end of 2011) by branch within period of 2004-2011 (position at the end of the period). Source (data): Bank of Latvia [24]

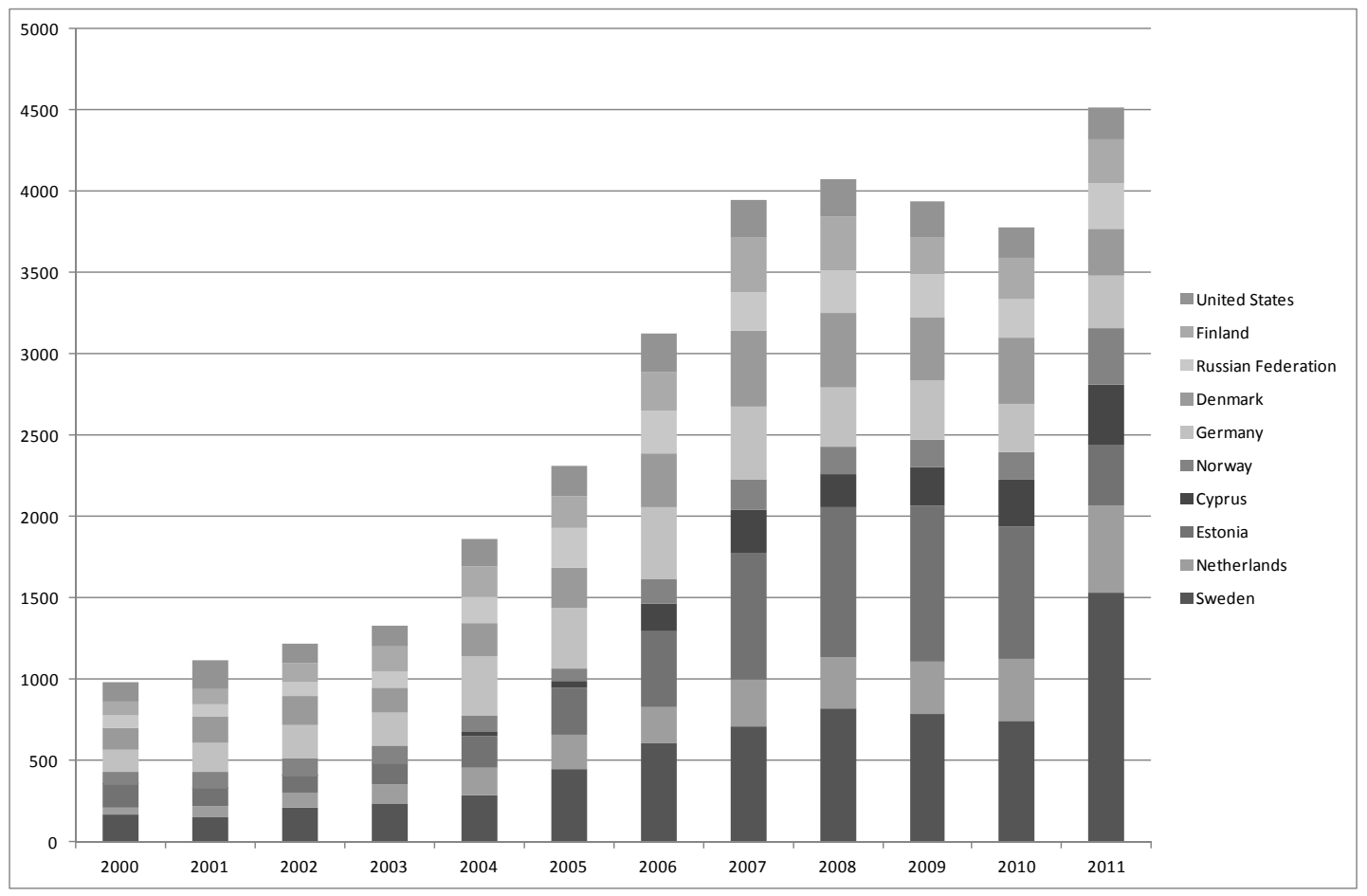

Figure 7. Ten most important FDI countries (in million Lats) for Latvia (ascending order with most recent year, 2011). Source (data): Bank of Latvia [24] 


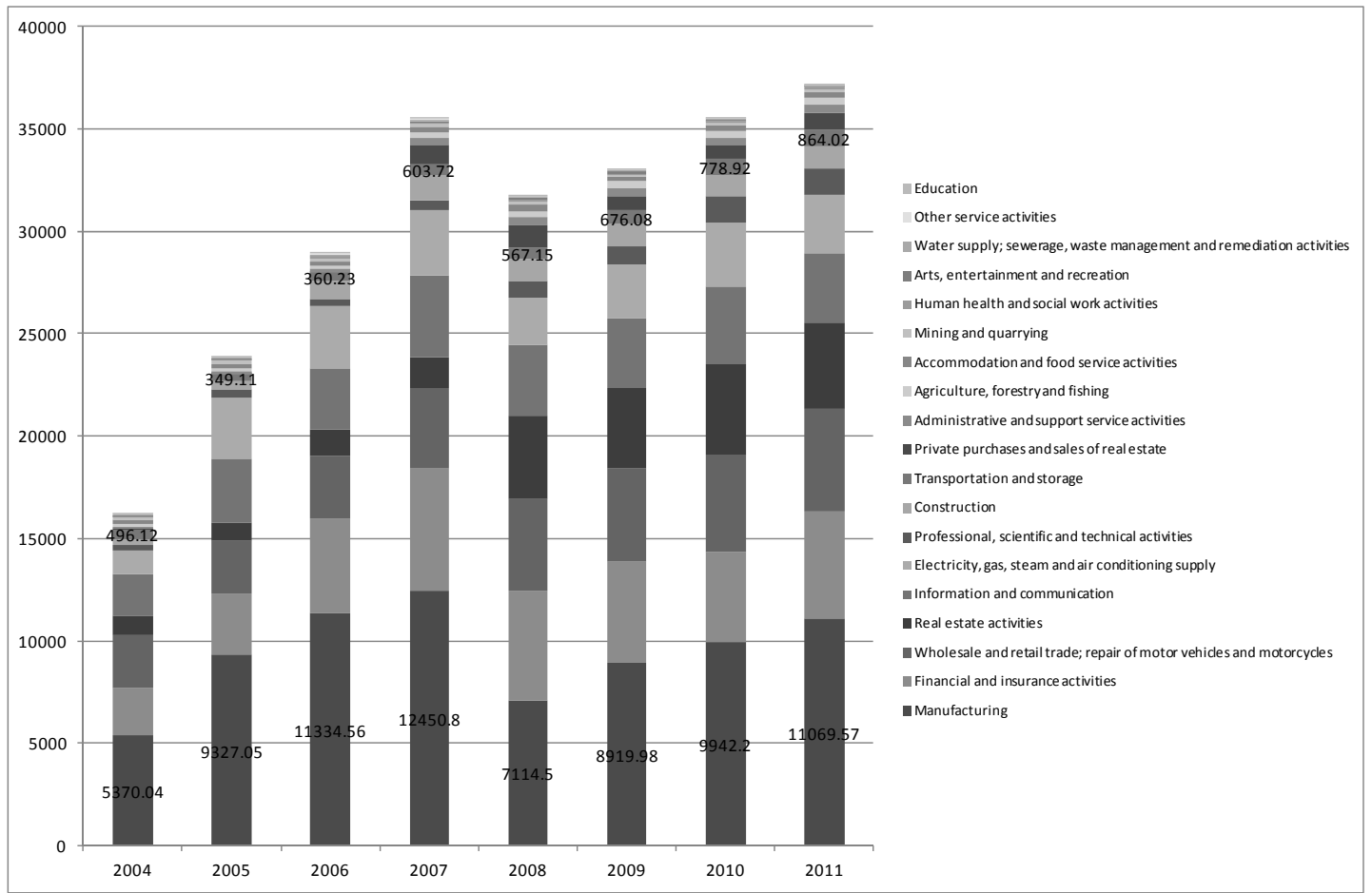

Figure 8. Foreign Direct Investments to Lithuania (in million LTL as 1 Lita was 0.29 Euros at the end of 2011) by branch within period of 2004-2011 (position at the end of the period). Source (data): Lithuanian Central Bank [25]

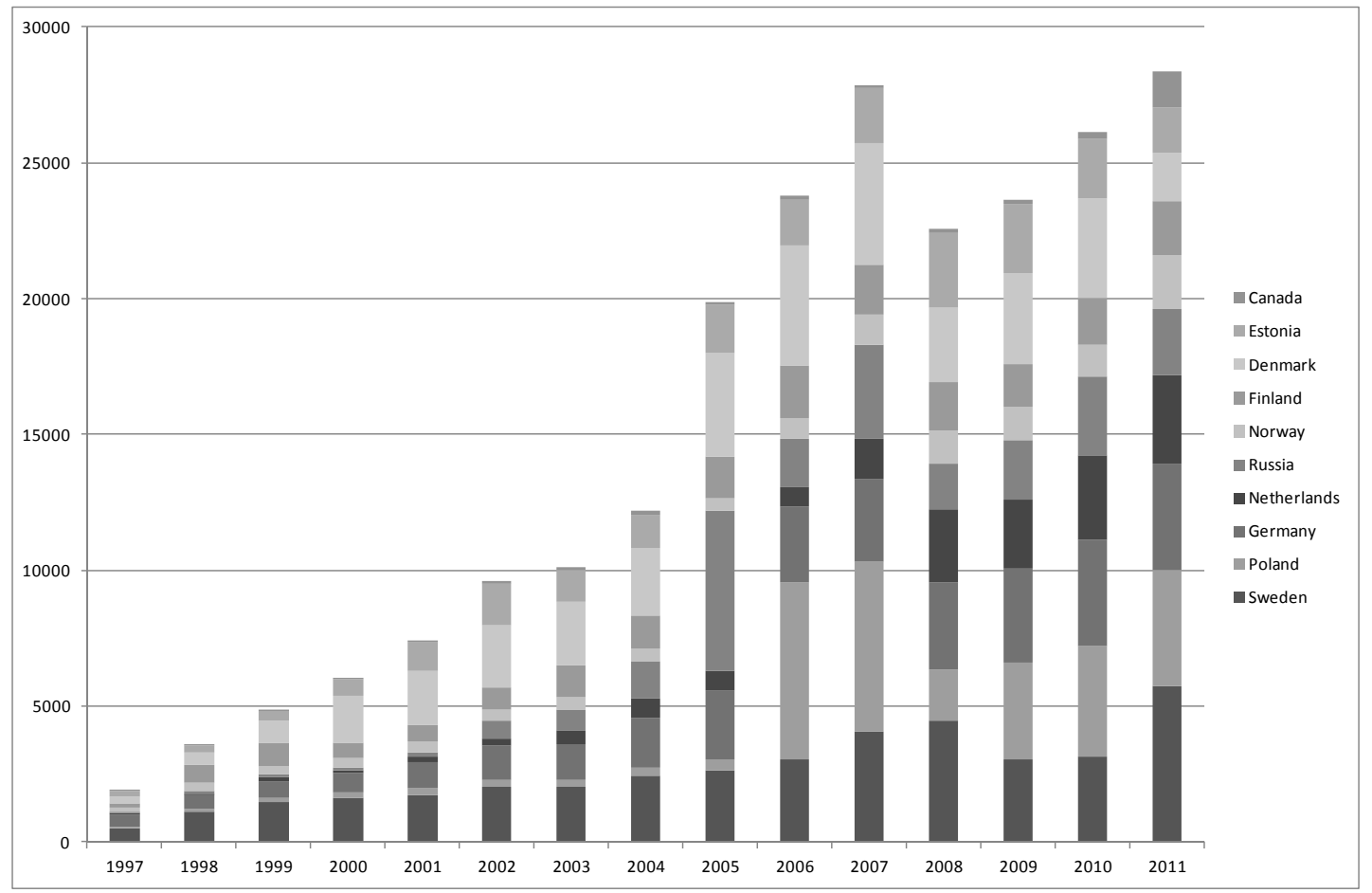

Figure 9. Ten most important FDI countries (in million LTL) for Lithuania (ascending order with most recent year, 2011). Source (data): Lithuanian Central Bank [25]

In country and Baltic Sea perspective, Sweden and Finland have been active in seeing and acting upon FDI front in all the Baltic States (Figures 5, 7, and 9). However, it should be emphasized that Sweden has been extremely active in Latvia and Lithuania, while Finland has been mostly interested from Estonia. Investments differ in a manner that Swedish activity is centred in banking sector. Along these 
two countries, Germany and Netherlands are present in ten most active countries of FDI in all the Baltic States. Also Estonia has been active in other two Baltic States, but mostly so in Latvia. Country peculiarities exist too, like high importance of France and Luxemburg in Estonia and Poland in Lithuania.

As it is today with employment and export manufacturing competence [26], it is also so with overall FDI attraction during observation period: Estonia leads in absolute amounts two other Baltic States, and its FDI activity was not that greatly interrupted by credit crunch. It should be noted that Estonia is having clearly the lowest population from all of the evaluated countries.

Analysed time period in three Baltic States is over-emphasizing importance of finance and real estate sectors - as these were the boom sectors during the late IT bubble burst era. However, it should be reminded that in the Baltic States main FDI target sectors were during 90's telecommunications and transports, but also in parts manufacturing. It could be explained that these sectors prospered as advances of mobile telecommunications were rapidly developing and neighbourhood countries, like Sweden and Finland, had leading positions in them (e.g. during 1999 from Estonian FDI Sweden and Finland together accounted 70\%; see Lesser [27]). So, on the other hand these two countries were active (with Danish) in FDI not only in telecommunication sector (operators), but also in related manufacturing of devices and infrastructure. Transportation sector received vast interest, too, but it did not turn out to be a high success within eastern transit business. For example, Latvian stock market listed from governmental program, Ventspils Nafta (transit business of oil and petroleum, mentioned as case already in Ojala \& Queiroz [28]), did not turn out as a major success (it has profitability, but not growth story), and could be eyed as an example that huge growth in this sector was and still is not in sight in the Baltic States. Similar constrained growth story could be set up from Estonian transit oil business and railway freight company privatisation, and later on its followed re-nationalization [29-30]. However, these could be rapidly changed to growth mode as in year 2015 very tight sulphur regulation takes off in the entire Baltic Sea region. This means that short sea shipping becomes expensive (30-40\%; [14; 31]) and actors will most probably minimize shipping route lengths (particularly important for east originating raw material export).

\section{Role of International Lending Organizations}

Among cohesion funds of European Union, international lending organizations such as European Bank for Reconstruction and Development (EBRD), European Investment Bank (EIB), Nordic Investment Bank (NIB) and World Bank have played important role in the support of the development of economies in the Baltic States (comprehensive analysis from the past transportation logistics projects is given in [22; 28]). However, as all the Baltic States developed in economics terms so rapidly in recent decade time period, role of direct aid type of finance changed as loans. This also increased the presence of some banks, like EIB: Growth of lending in most recent observation period (years 2008-2012) increased by factor of 3-5 times. Figure 10 illustrates this drastic change further. However, it should be emphasized that EIB loans have mostly been taken during years 2008-2009 in the most recent spike period (detailed analysis on [32]).

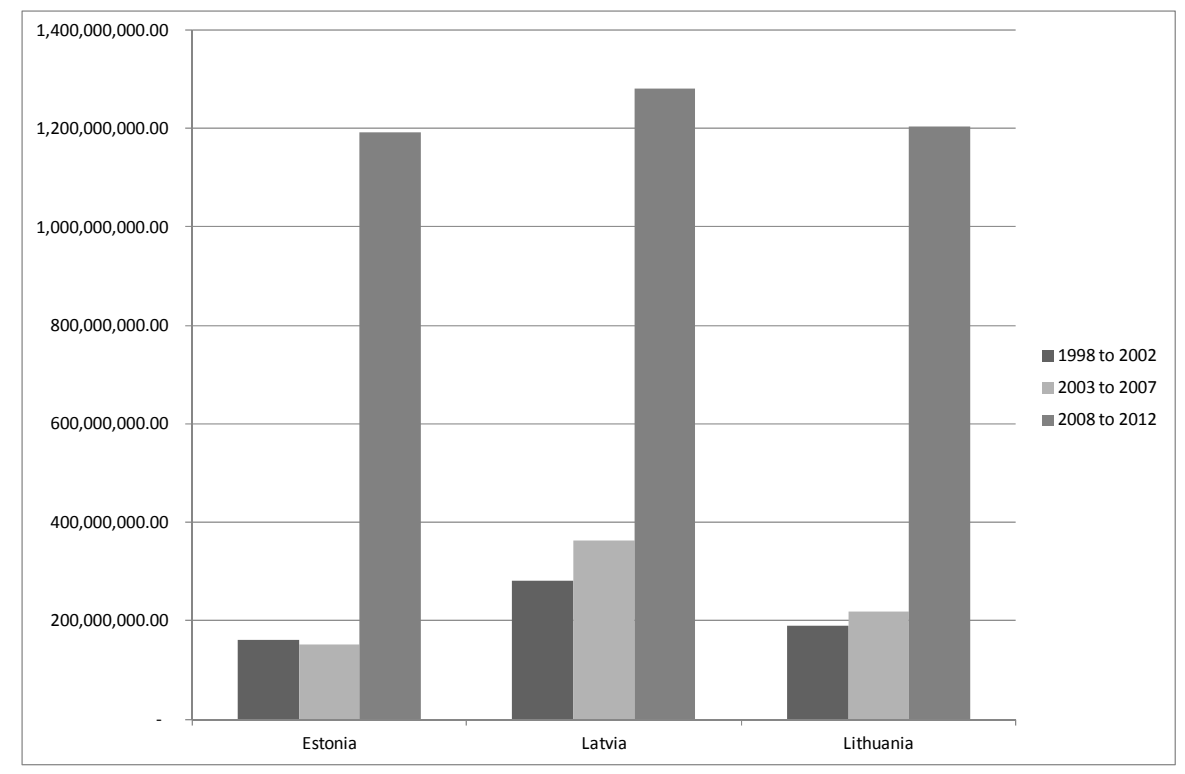

Figure 10. Amount of European Investment Bank (EIB) loans (in Euros) for the Baltic States during period of 1998-2012 (March). Source: EIB [33] 
Although funding amounts have increased significantly from EIB, they have concerned transport, energy or industrial sectors in recent analysed period (2008-2012) with not that impressive share. At least this is the case of Latvia and Lithuania (25\% from overall funding; Tables 2 and 3). In Latvia only company investing in large-scale into energy sector is state-owned Latvenergo, which is replacing old gas turbines and improving distribution network. EIB finance is 200 million EUR, but it should be reminded that EBRD provides additional 150 million EUR for this large project [38]. Apart from EU project cofinancing loans, in Lithuania minor activity exist with further improvement of freight trains (have already started in period of 2003-2007) and small-scale industrial development loans.

Table 1. EIB financed projects in Estonia (in Euros) within transportation and energy sectors (period of 2008-2012). Source: EIB [33]

Project
\begin{tabular}{|l|l|r|r|}
\multicolumn{1}{l}{ Sector } & \multicolumn{1}{l}{ Signature } & \multicolumn{1}{l}{ Amount } \\
\hline \hline TALLINK RO-PAX II & Transport & $18 / 12 / 09$ & $90,000,000.00$ \\
\hline MUUGA HARBOUR INTERMODAL FACILITIES & Transport & $14 / 12 / 09$ & $11,500,000.00$ \\
\hline EU FUNDS CO-FINANCING 2007-2013(EST) & Transport & $25 / 05 / 09$ & $115,500,000.00$ \\
\hline PORT OF TALLINN EXPANSION & Transport & $12 / 02 / 09$ & $40,000,000.00$ \\
\hline TALLINN MUNICIPAL INFRASTRUCTURE & Transport & $19 / 11 / 08$ & $31,955,000.00$ \\
\hline TALLINK ROPAX & Transport & $27 / 06 / 08$ & $25,000,000.00$ \\
\hline
\end{tabular}

\begin{tabular}{|c|c|c|c|}
\hline \multirow[b]{2}{*}{ Project } & \multirow[b]{2}{*}{ Sector } & \multicolumn{2}{|c|}{ Total: $\quad 313,955,000.00$} \\
\hline & & Signature & Amount \\
\hline EESTI ENERGIA WINDPARKS & Energy & $08 / 12 / 11$ & 45,000,000.00 \\
\hline EESTI ENERGIA WTE & Energy & $08 / 12 / 11$ & $25,000,000.00$ \\
\hline ESTLINK 2 TEN-E & Energy & $18 / 11 / 10$ & $75,000,000.00$ \\
\hline EESTI ENERGIA POWER NETWORKS & Energy & $25 / 05 / 09$ & $150,000,000.00$ \\
\hline
\end{tabular}

Table 2. EIB financed projects in Latvia (in Euros) within energy sector (period of 2008-2012). Source: EIB [33]

\begin{tabular}{|c|c|c|c|}
\hline Project & Sector & Signature & Amount \\
\hline LATVENERGO CHP & Energy & |02/10/09 & $100,000,000.00$ \\
\hline $\begin{array}{l}\text { LATVENERGO POWER } \\
\text { DISTRIBUTION }\end{array}$ & Energy & $24 / 10 / 08$ & $100,000,000.00$ \\
\hline
\end{tabular}

Total: $\quad 200,000,000.00$

Table 3. EIB financed projects in Lithuania (in Euros) within transport and industry sectors (period of 2008-2012). Source: EIB [33]

Project

\begin{tabular}{|c|c|c|c|}
\hline Project & Sector & Signature & Amount \\
\hline CIE AUTOMOTIVE MULTITECHNOLOGY PARTS & Industry & $23 / 12 / 09$ & $3,000,000.00$ \\
\hline WIENERBERGER PRODUCTION DEVELOPMENT & Industry & $03 / 12 / 09$ & $19,000,000.00$ \\
\hline LITHUANIAN RAILW A YS II - LOCOMOTIVES & Transport & $29 / 03 / 10$ & $20,000,000.00$ \\
\hline EU FUNDS CO-FINANCING 2007-2013 (LT) & Transport & $13 / 03 / 09$ & $226,400,000.00$ \\
\hline & & Total: & $268,400,000.00$ \\
\hline
\end{tabular}

Estonian industrial and energy sector project portfolio looks more diverse and double to that of two other Baltic States (Table 1). In Transport sector improvements are targeted to the maritime sub-branch, which is natural, since Tallink Silja is one of the leading short sea shipping companies in the Baltic Sea. Table 1 shows, how this operator modernized its fleet couple of years ago. Also improvement projects have been completed in Tallinn sea port (the largest passenger sea port in the Baltic States), and sea port's industrial terminal located in Muuga. Similar to Latvia, electric network and power generation 
is under renewal in Estonia. It is important to note that electricity distribution is not only improved within Estonia domestically, but investment project of linking Estonian electricity network to Finland (submarine cable, ESTLINK 2 TEN-E) also consists. Notable is the role of wind energy, which has also been supported by EBRD [34]. In overall solution for future energy needs, Estonia relies upon oil shale based energy production in the future, too. It recently selected Alstom to supply power plant close to Narva (plant called as Auvere; [35]). It is unclear how finance of this power plant has been case specifically organized (operational in 2015), however, it should be noted that Eesti Energia gathered 300 mill. Euros with bond sale from European investors in March 2011 [36].

In most recent information from EBRD [37], it is reported that they are committed in the funding of the new energy production capacity of Lithuania. This was due to the closure of Ignalina Nuclear Power Plant (large-scale facility, which was closed in the end of 2009, major producer of electricity, even contributing to export). Based on EBRD [37] brochures, help in energy production is being implemented with the renewal of old gas turbines at Lietuvos Elektrine - sharing similarities with Latvia's gas investments.

\section{EU Cohesion Funding}

All three Baltic States became full members of European Union (EU) during May.2004. Until today only Estonia is also member of monetary union, Euro, while Latvia and Lithuania have still in use national currencies (Latvia has ambitious plan to enter monetary union in the early 2014). EU membership has enabled all three countries to access important cohesion funds (in here incl. European Regional Development Fund, European Social Fund and Cohesion Fund), which are given for the development of economically less developed regions in Europe. For program period of 2007-2013 total sums were as follows [39]: 3.4 bill. Euros for Estonia, 4.6 bill. Euros for Latvia and 6.8 bill. Euros for Lithuania. In comparison, more or less similarly sized with the Baltic States, Finland and Sweden received 1.7 bill. Euros and 1.9 bill. Euros, respectively. So, due to economical situation, the Baltic States attracted nearly eight times development funds as compared to neighbours in west or north. These large sums of development funds are not only intended for transportation infrastructure or manufacturing industry development, but are used to improve and protect environment, foster R\&D and innovation as well as healthcare (EU Structural Assistance to Estonia, 2013). It could be assumed that one third or one fourth from total funds will be devoted to transportation infrastructure.

The Baltic States were able to enter EU cohesion funds partly during program period of 20002006, as EU accession was completed in May.2004. However, funding in this period was rather limited. For transportation infrastructure the following sums were granted [4]: 233 mill. Euros for Estonia, 409 mill. Euros for Latvia and 208 mill. Euros for Lithuania. For the author other granted sums are unknown. Anyway, even if funding sums seem to be rather small, it should be remembered that for the Baltic States these sums were still significant in years 2004-2006. Also it should be noted that program period was only three years long.

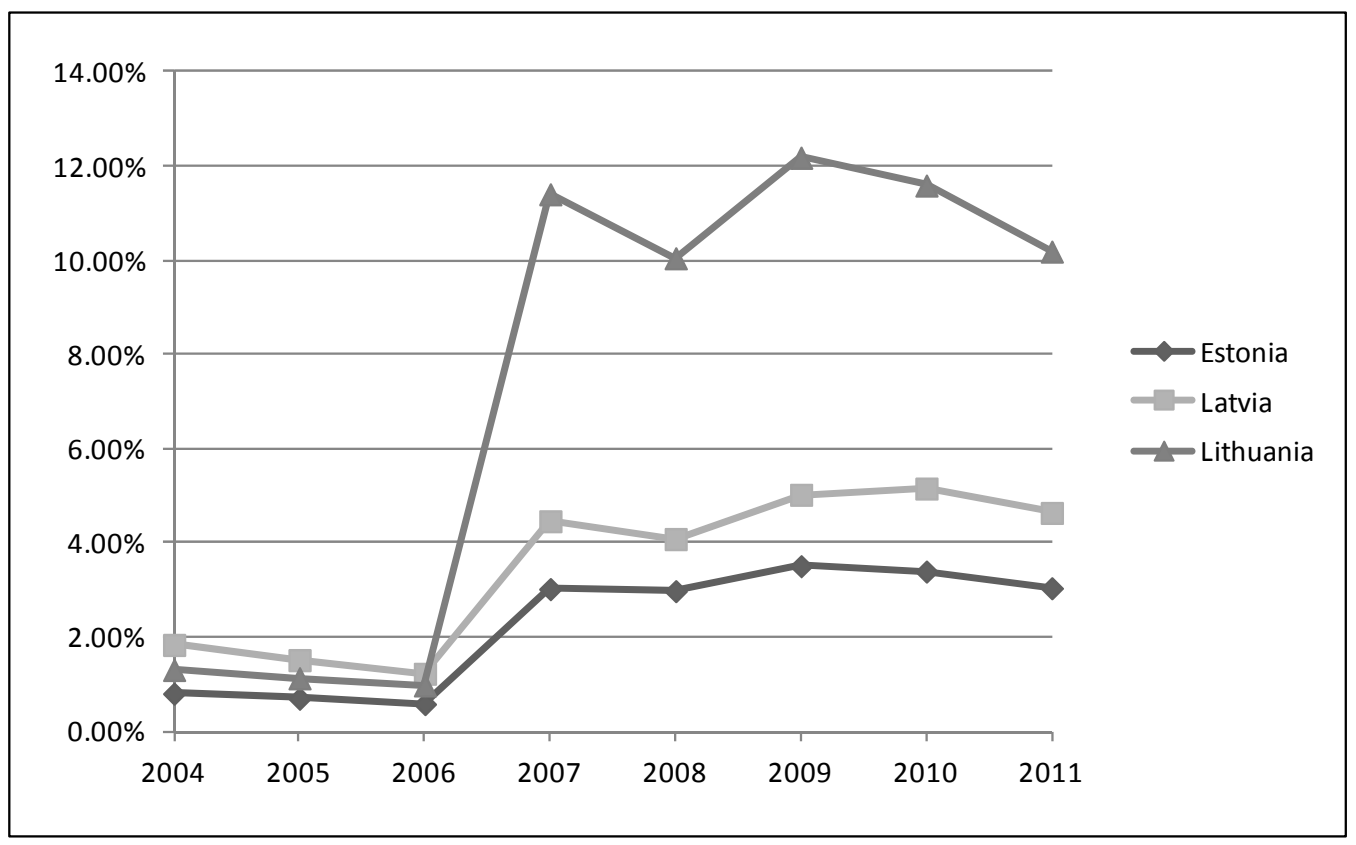

Figure 11. Share of EU Cohesion funds in the Baltic States from GDP during years 2004-2011 
Importance of EU cohesion funds is illustrated on Figure 11 by estimating what is their share from respective year's GDP. In here we have distributed cohesion funds equally to program period, and for the years 2004-2006 is only devoted these known transportation infrastructure funds. At first glance it is inevitable that especially most recent program period has played key role in the economy development. It could be even argued that for Lithuania these funds play too large role, and dependence as well as economy overheating could be caused by these. It could also be argued that without this funding, all the Baltic States would have suffered even more from credit crunch, and their recovery would have been much more fragile. Without a doubt these funds have played key role as an instrument to stimulate the economies. However, as all the Baltic States have continued to recover and show GDP growth, share of EU Cohesion funds has continued to decline in year 2012.

\section{Conclusions}

As emerging economies, the Baltic States have attracted significant amount of FDI after late 90's. However, this rapid growth of FDI stock showed levelling off development during year 2009 in Estonia and Latvia - in Lithuania year 2008 was showing decline. Based on our analysis, important and largescale loans were available in this moment, but were mostly used in years 2008-2009. Thereafter, three Baltic economies have showed rather cautious approach for making investments. However, in positive respect effect of credit crunch was short-term lived, and FDI has started again to increase in all countries (has continued also in the most recent year 2012). This growth has its limits, since very robust growth has been caused earlier by domestic oriented sectors (finance, real estate, construction and retail), and growth from now onwards need to be attracted out of export oriented sectors (like manufacturing and transport). Until today all the Baltic States have only shown trade account deficits - these have slightly improved as compared to time before crisis, but still are notably on negative side. Opportunities lie ahead as great environmental legislation changes take off in the Baltic Sea region (starting from sulphur ban in year 2015). These will mean that shorter routes at sea and longer journeys in hinterlands will become reality. All three Baltic States could be seen as hinterland for its northern and southern neighbours, and therefore strengthening this axis together with old strengths of raw material transit export are lucrative investment places for future.

As all three Baltic State economies are rather small ones in absolute terms, it is rather fortunate for them that they joined EU already during year 2004. From current EU cohesion funds the Baltic countries (among other east and south European counterparts) receive relatively high sums. This enables them to renew e.g. transportation infrastructure in large-scale. Even if instrument could be seen as stimulating element, it should be connected more on attracting FDI inflows, too. So, these infrastructure investments should enable higher amount of transit transports through the Baltic States, and as well support inauguration of export based manufacturing industries. Of course, it is problematic in EU cohesion funding perspective to support these, but taking into account this perspective, together with population well-being, should not be impossible. However, measures should be integrated into the most important area of economic development: Improving trade deficit in all three countries, and in particular Latvia and Lithuania. Current situation in these two mentioned countries resembles too much life before crisis, which does not lead to sustained growth (actually will lead to great bubbles ahead). Slow, but clear manufacturing job growth should be secured in the forthcoming years. Still today one fifth of manufacturing jobs are missing as compared to early 2008.

For the further research, we would be interested to build a model (analytical or simulation), which would take into account different forms of capital inflows in economically less-developed countries in Europe, and also estimate role of capital inflows into development of GDP. Most probably private and public sector attraction of funds plays a key role. For the future development we would like to seek countries or regions, where these attracted funds have resulted on investments and renaissance of export based industries. Without this important link, fund inflows are just a cause of yet another recession as business confidence erodes for one reason or the other. This again leads to massive unemployment, which is entirely undesired outcome in the current state of European economy.

\section{References}

1. Kumpikaite, Vilmante, Grybauskas, Andrius, Juodelis, Mantas \& Strumyla, Dovydas. (2011). Companies’ management during economic crisis. International Scientific Conference on Economics and Management (Brno, Czech Republic). Journal of Economics and Management, 16, 789-795. 
2. Sakiene, Henrika. (2011). Regional unemployment regulation during economic slowdown in Lithuania. International Scientific Conference on Economics and Management (Brno, Czech Republic). Journal of Economics and Management, 16, 309-315.

3. Bobinaite, Viktorija, Juozapaviciene, Aldona \& Konstantinaviciute, Inga. (2011). Regression analysis of gross domestic product and its factors in Lithuania. International Scientific Conference on Economics and Management (Brno, Czech Republic). Journal of Economics and Management, 16, 116-126.

4. Priede, Janis \& Skapars, Roberts. (2012). Quality competitiveness of Latvia's metal industry in the iron and steel product groups. International Scientific Conference on Economics and Management (Tallinn, Estonia). Journal of Economics and Management, 17, 202-208.

5. Saboniene, Asta. (2011a). The changes of Lithuanian export competitiveness in the context of economic crisis. International Scientific Conference on Economics and Management (Brno, Czech Republic). Journal of Economics and Management, 16, 302-308.

6. Shatrevich, Vladimir \& Zvanitajs, Janis. (2011). Labor productivity research for Latvian production branch export companies. International Scientific Conference on Economics and Management (Brno, Czech Republic). Journal of Economics and Management, 16, 316-322.

7. Veveris, Armands \& Kalis, Ilmars. (2011). The impact of EU agricultural policy on the competitiveness of the farms in Latvia. International Scientific Conference on Economics and Management (Brno, Czech Republic). Journal of Economics and Management, 16, 452-458.

8. Saboniene, Asta. (2011b). The transformation of Lithuanian economy: Dimension of manufacturing. International Scientific Conference on Economics and Management (Brno, Czech Republic). Journal of Economics and Management, 16, 295-301.

9. Bernatonyte (2012). Changes of Lithuanian intra-industry trade in light of the economic crisis. International Scientific Conference on Economics and Management (Tallinn, Estonia. Journal of Economics and Management, 17, 110-116.

10. Kleesmaa, Juri, Viiding, Marko \& Latosov, Eduard. (2011). Implications for competitiveness of the Estonian carbon-intensive industry post-2013. Baltic Journal of Economics, 11(2), 41-58.

11. Dumciuviene, Daiva. (2011). Economic development and cohesion policy as financial instrument. International Scientific Conference on Economics and Management (Brno, Czech Republic). Journal of Economics and Management, 16, 167-172.

12. EU Structural Assistance to Estonia. (2013). European Union Structural Assistance to Estonia. Webpages. Retrieved: April. 2013, from URL: www.struktuurifondid.ee

13. Hilmola, Olli-Pekka. (2011). Rail Baltica Influence Area: State of Operating Environment. Lappeenranta University of Technology, Department of Industrial Management. Research Report 236.

14. Hilmola, Olli-Pekka. (2012). Competing Transportation Chains in Helsinki-Tallinn Route: MultiDimensional Evaluation. Lappeenranta University of Technology, Department of Industrial Management. Research Report 243.

15. BOF (2012). Exchange rates database of Bank of Finland. Retrieved May.2013, from http://www.suomenpankki.fi/en/tilastot/valuuttakurssit/Pages/tilastot_valuuttakurssit_valuuttakurssit _long_en.aspx

16. Statistics Estonia. (2012). Gross domestic product by expenditure approach. Retrieved April.2013, from http://pub.stat.ee/px-

web.2001/I_Databas/Economy/23National_accounts/01Gross_domestic_product_(GDP)/06Gross_do mestic_product_by_expenditure_approach/06Gross_domestic_product_by_expenditure_approach.asp

17. Central Statistical Bureau of Latvia. (2012). Available tables on Gross Domestic Product. Retrieved April. 2013, from

http://data.csb.gov.lv/DATABASEEN/ekfin/Annual\%20statistical\%20data/02.\%20Gross\%20domest ic\%20product/02.\%20Gross\%20domestic\%20product.asp

18. Statistics Lithuania. (2012). Gross domestic product (GDP). Retrieved April, 2013, from http://db1.stat.gov.lt/statbank/SelectVarVal/Define.asp?Maintable=M2010201\&PLanguage=1

19. UN Comtrade. (2012). International Merchandise Trade Statistics. Retrieved April.2013, from http://comtrade.un.org/

20. Credit Suisse. (2006). Credit Suisse Discovers the “Baltic Tigers”. Retrieved August 2012, from https://infocus.creditsuisse.com/app/article/index.cfm?aoid=159202\&fuseaction=OpenArticle\&lang=EN

21. The Economist. (2003). Lithuania: Baltic tiger. The Economist, $17^{\text {th }}$ of July. Retrieved August 2012, from http://www.economist.com/node/1929205 
22. Ojala, Lauri, Naula, Tapio \& Queiroz, Cesar. (2005). Transport Sector Restructuring in the Baltic States as Members of the European Union. In Proceedings of the 3rd Seminar Held in Vilnius. Turku, Finland: School of Economics.

23. Bank of Estonia. (2012). Statistics of Central Bank. Retrieved April 2013, from http://www.eestipank.info/pub/en/dokumendid/statistika/

24. Bank of Latvia. (2012). Statistics of Central Bank. Retrieved April 2013, from http://www.bank.lv/en/statistics/activities/

25. Lithuanian Central Bank. (2012). Statistics of Central Bank. Retrieved April 2013, from http://www.lb.lt/statistical_data_tree

26. Bernatonyte (2011). Export productivity and specialization patterns of Lithuania. International Scientific Conference on Economics and Management (Brno, Czech Republic). Journal of Economics and Management, 16, 109-115.

27. Lesser, Barry. (2000). BALT-ECON 2000: Economic Policy, and Reform in Estonia, Latvia and Lithuania, 1992 to 2000 and Beyond. Baltic Economic Management Training Program. Halifax, Canada.

28. Ojala, Lauri \& Queiroz, Cesar. (2001). Transport Sector Restructuring in the Baltic States. In Proceedings of a Seminar held in Riga on November 16-17, 2000. Turku, Finland: Turku School of Economics and World Bank.

29. Laisi, Milla \& Poikolainen, Tiina. (2011). Progression of the Deregulation in the North European Railway Passenger Markets - Building Insights via Customer Satisfaction Survey and Expert Interviews, 15/2011. Helsinki, Finland: Finnish Transport Agency.

30. Terk, Erik, Tapaninen, Ulla, Hilmola, Olli-Pekka \& Hunt, Tonis. (2007). Oil Transit in Estonia and Finland - Current Status, Future Demand, and Implications on Infrastructure Investments in Transportation Chain. In Publications of Estonian Maritime Academy, No. 4, 2007.

31. Karamysheva, Marina, Henttu, Ville \& Hilmola, Olli-Pekka. (2013). Logistics of North-West Russia and Rail Baltica: Standpoints of Private Sector. Lappeenranta University of Technology, Department of Industrial Management. LUT Scientific and Expertise Publications. Research Report 3.

32. Ketels, Christian. (2012). State of the Region Report 2012 - The Top of Europe Bracing Itself for Difficult Times: Baltic Sea Region-Collaboration to Sustain Growth. Baltic Development Forum, Copenhagen, Denmark.

33. EIB. (2012). Finance Contracts Signed - Breakdown by Region. Retrieved April 2012, from http://www.eib.org/projects/loans/regions/european-union/index.htm

34. EBRD. (2012a). Estonian factsheet. Retrieved April 2012, from URL: www.ebrd.com/estonia

35. Eesti Energia. (2012). Eesti Energia lays cornerstone for Auvere power plant. Press release on $4^{\text {th }}$ of May.

36. Eesti Energia. (2011). Eesti Energia borrows 300 million for financing domestic investments. Press release on $26^{\text {th }}$ of March.

37. EBRD. (2012c). Lithuanian factsheet. Retrieved April 2012, from URL: www.ebrd.com/lithuania

38. EBRD (2012b). Latvian factsheet. Retrieved April 2012, from URL: www.ebrd.com/latvia

39. EU Regio. (2012). Regional Policy - Inforegio. Retrieved June 2012, from http://ec.europa.eu/regional_policy/index_en.cfm

40. Gleave, Steer Davies. (2010). Ex Post Evaluation of Cohesion Policy Programmes 2000-2006 Co-Financed by the European Fund for Regional Development (Objectives 1 \& 2) - Work Package 5A: Transport. Final Report for European Commission (DG Regio), London.

41. Atukeren, Erdal. (2011). Macroeconomic effect of high oil prices on the Swiss economy: 2003-2008. International Journal of Sustainable Economy, 3(1), 1-19. 